\title{
As below, so above: \\ A perspective on African Theology
}

\author{
Arno Meiring ${ }^{1}$ \\ Department of Science of Religion and Missiology \\ University of Pretoria
}

\begin{abstract}
African theology can be understood as a theology from below - or rather, "as below, so above". This phrase not only reflects the concept of ubuntu and the African partiality towards horizontal relationships, but may help explain African perspectives on shame and guilt, sin and reconciliation, liberation, the ancestors and eschatology. Subsequently, there seems to be some concurrence between African theology and Western postmodern theology. Although these theologies challenge traditional theology, and should in turn be scrutinized, they may offer useful and valid ways of thinking and speaking about God.
\end{abstract}

\section{INTRODUCTION}

African Theology is hailed by many as an important perspective and indispensable contribution in Christian thinking about God. After centuries in which Western theology and philosophy dominated theology in South Africa, the unique insights of the African theologians were at last recognised since the middle of the $20^{\text {th }}$ century. With good reason: Not only have African theologians interpreted the Gospel in ways to address the specific context(s) of Africa, but many would (in my opinion, rightly) add that African Traditional Religion (which often informs African Theology), is quite compatible with the message and worldview of the Bible and can enhance our view of God (Bediako 1995:97; Mbiti 1969:29; 1998:140-142). John Mbiti (1998:142) asserts that: "The Bible is very much an African book, in which African Christians and theologians see themselves and their people reflected and in which they find a personal place of dignity and acceptance before God."

\footnotetext{
${ }^{1}$ This article is based on Arno Meiring's PhD dissertation (2006), entitled "Heart of darkness: A deconstruction of traditional Christian concepts of reconciliation by means of a religious studies perspective on the Christian and African religions". The dissertation was prepared under the supervision of Prof Dr P G J Meiring, Department of Science of Religion and Missiology, Faculty of Theology, University of Pretoria (2006).
} 
It is however not easy to determine exactly what African Theology is. Although most South African Christians greatly appreciate the teachings of African (and Black) theologians, and perhaps especially their role during the liberation struggle, it is hard to establish a single common denominator in their writings. Some would typify African Theology as theology of liberation, either from colonialism (as in Black Theology) or from physical and spiritual affliction (as many AIC theologians might say). Others, such as Gabriel Setiloane, see African Theology as a theology of solidarity, or as a theology of healing, even of ecology and of harmony. It seems that African Theology may mean a number of different things for different theologians (Hayes 1998:175, 176; Khathide 2004:1; Landman 1998:137; Mbiti 1998:154; Musopole 1993:348; Ndungane 2003:104; Setiloane 1976:128-131).

I believe that to really appreciate the African contribution to our understanding of God, a single and all-encompassing idea which could bring to light what I can learn from African Theology is necessary. In this article I investigate one such possibility.

\section{A REFLECTIVE APPROACH}

As a student of mostly Western theological traditions, I do not pretend to understand either African Traditional Religion or African Theology as an insider. Still, I believe that I can reasonably explore African Theology through a reflective approach ${ }^{2}$. According to this method, I reflect on my experience of African Theology rather than try to explain it as an object - in this way bridging the gulf between subject and object by projecting my own experiences onto

\footnotetext{
${ }^{2}$ This problem has been answered in at least four different ways. Following the 19th century distinction between Geisteswissenschaften and Naturwissenschaften, the first effort focussed on the human spirit human desires, hopes, fears; human meanings and intentions as a possible bridge between the subject and the object. The phenomenological research method empathetically described human behaviour in an (rather optimistic) attempt to understand and interpret others' experiences (McCutcheon 1999:3).

A second option considered the scholar's ability to get inside the subject as virtually impossible and instead concentrated on developing theories capable of explaining the complex patterns of human behaviour. Coinciding with the development of psychoanalysis, this reductionist approach is based on studying only that which can be observed empirically. The goal is to determine the causes and regularities of human actions and beliefs, which may differ from the explanations that the insiders themselves supply for their actions (McCutcheon 1999:4).

Where the focus on only studying private experiences seems to validate the claims of the insider all too quickly, and where the emphasis on developing explanatory theories can all too easily dismiss insiders claims, the third option attempted to remain neutral when it comes to questions of truth and value but emphasised issues of accurate description and comparison the expense of drawing value judgements. The methodological agnosticism simply described the diversity, similarity and utter complexity of human behaviours and beliefs but avoids asking all questions concerning the truth of someone's claims (McCutcheon 1999:6-8).

In addition to these three positions (empathetic, explanatory, agnostic), there is a fourth approach to the insider/outsider problem. It agrees in part with the first option: it is indeed important to study the inner states and experiences of free, creative human beings. However, it also agrees in part with the second: there is a significant gap between the researcher and the subject. Finally, it differs significantly from the third in that the researcher and the subject alike are both seen to be enmeshed in the human situation, making this much sought after neutrality a mere illusion. "The conclusion in this case is that the experiences that we as scholars are able to study are none other than our own." (McCutcheon 1999:8.)
} 
African Theology, hence my personal style (McCutcheon 1999:9). In this study I therefore formulate my suggestion, examine whether it is consistent with a number of issues within African Theology and evaluate its relative significance.

\section{AS BELOW, SO ABOVE}

According to numerous (esoteric) traditions, the Egyptian, Hermes Trismegistus (possibly $5500 \mathrm{BCE}$ ) first coined the phrase "As above, so below; as below, so above" in the fabled Emerald Tablet. He believed that there was a link between the spiritual world and the physical reality, and that what happened on one level could influence the other. This idea has since meticulously been explored by all kinds of alchemists and mystics (Bailey 2006:1). Despite its less than scientific origin, I would like to suggest that if we modify the African mystic's phrase, it may present a key to the understanding of African Theology as a whole. I would like to venture that African Theology can be summarised in the (slightly nuanced) dictum: As below, so above.

Allow me to quote some well known examples (on which there is general agreement):

\subsection{Ubuntu}

The African worldview emphasises the importance of the community more than most, and this is summed up in the well-known concept of ubuntu: I am because we are. While students of the Enlightenment would say "I think, therefore I am", Africans say: "I belong, therefore I am". An African is a beingin-community (Adeyemo 1998:374; Gerloff 1998:49; Ndungane 2003:102; Setiloane 2000:21; Tutu 1999:35). This belief in the community often contradicts Western notions of individuality. John Mbiti (2005:1) relates, for example, that when a husband and wife have marital problems, the whole community gets involved in an effort to reconcile the partners. Similarly, African people say "we have been killed" if one member of their community was killed, and not only the offender, but the whole community takes responsibility for the misdeed.

This community does not only include human beings, but also nature, the world of the spirits, ancestors and even God. Du Toit (1998:398) calls it a kinship with nature in which animals and plants, like human beings, have their own spiritual existence and place in the universe as interdependent parts of a whole:

African ontology considers God, spirits, humans, animals, plants and inanimate creation to be one. To break up this unity is to 
destroy one or more of these modes of existence, and to destroy one is in effect to destroy them all.

It follows that humans' relationship with one another has an effect on all the relations in this interdependent universe. An individual, who neglects his or her ancestors, is simultaneously, inevitably, in conflict with other humans beings or nature. Likewise, natural disasters point to tension or disharmony in the community. God is also part of this balance. An offence against another human, element of nature or ancestors, is seen as an offence to God. Put differently, service to God demands, first and foremost, service to the community.

\subsection{Horizontal and vertical dimensions}

Theologians often distinguish between our horizontal and vertical relations and obligations. Our vertical relationship refers to our relationship with God, while our horizontal relationship entails our dealings with God's creatures. In traditional theology, both these dimensions are important and emphasised. The difference lies in the sequence. Western Theology with some exceptions ${ }^{3}$ emphasised that the vertical dimension precedes the horizontal. Our relationship with God determines our relationship with the rest of creation; a broken relationship with God leads to strife among humans and struggle against nature. Similarly, our relationship with one another can only be restored by first being reconciled to God (Huber 1990:43; Van der Kooi, 2002:105-106; Steyn 2005:133).

Western Christianity thus seems to be more otherworldly inclined and focuses more on the vertical dimension than on the horizontal. This does not mean that Western theologians do not take the horizontal dimension seriously. The relationship between fellow human beings is as important for Christians as their relationship to God, and is a central tenet is the teachings of Christ. But it always follows from the spiritual relationship.

Addressing the question of reconciliation, for example, Van der Kooi (2002:104) argues that the Christian concept of reconciliation is built on the presupposition that a "real and comprehensive restoration of mutually amicable human relations has its ground and motive in the reconciliation of God with humankind". The healing of the relationship with God brings about human reconciliation on social, economic and political levels. This religious vertical focus, where found, may be due to a very strong undertone of dualism that still permeates Western Christianity (Kistner 1998:103).

\footnotetext{
${ }^{3}$ There are of course many exceptions, such as the $19^{\text {th }}$ century liberal theology, the Social Gospel Movement of the first half of the $20^{\text {th }}$ century, the Life and Work Movement and the open, this-worldly stance of the participants in the Genevan Ecumenical movement and the Liberation Theology.
} 
African Theology reverses the order. According to African thought, our relations within the community determine our relationship with God. And reconciliation starts with humans being reconciled. It is because African Theology is much more this-worldly focussed, and views the affairs of humans as all-important. Instead of a dualistic worldview, African people approach the world holistically, and believe that all creatures in creation are linked. When reconciliation is needed, their solution for it is to reconcile on a horizontal level, and to expect that the vertical dimension will follow from that (Bediako 1995:101; Ndungane 2003:101; Nyirongo 1997:61; Tutu 1996: xvi-xvii; Van Niekerk 1982:24).

Thorpe (1991:5) says that African religion is very much part of the society in which it is found. "It is thus oriented to this world and has a clear horizontal dimension". But African religion is also permeated by an awareness of the spiritual, invisible dimension of life:

Trees, rivers, streams, rain are more than merely things to be utilised. They have a spiritual quality which unites them to human beings in a greater cosmic whole. The ancestors or living-dead continue to be a spiritual part of this greater cosmos even after they have ceased to exist as a physical part. The creator, and even creation itself, belong to this vertical or spiritual dimension of ATR.

(Thorpe 1991:5)

It follows that Africans do take the vertical dimension seriously, but then the vertical dimension does not entail a dualistic worldview, but supposes God also being part of the community of all things.

\subsection{As below ....}

This horizontal focus is exactly what I referred to in my summarising of African Theology. According to Africa theology, the community, the horizontal constituting the "below", determines our relationship with God - the "above". This world establishes the other world.

This is the opposite of the traditional way of thinking about our relationship with God. I have shown that Western Theology predominantly teaches that the "above" determines the "below". African Theology focuses on the below to such an extent that even God becomes part of this world.

\section{APPLYING THE THEORY}

My theory needs to be tested. Is it a valid way of typifying African Theology and does it help us to make sense of Africa's contribution to theological 


\section{As below, so above: A perspective on African Theology}

thinking? Does it explain the various perspectives offered by African theologians on specific Christian issues? This requires to be investigated.

\subsection{Shame and guilt}

Van der Walt (2004:2) distinguishes between a Western and an African conscience. He explains that a good conscience according to the West requires justice (obedience to norms) and a bad conscience is the result of guilt (a transgression of norms). A guilty conscience is restored through reparation and retribution. In Africa, a good conscience is the result of honour and acceptance of the community through compliance with its ideals. It follows that a bad conscience results from one's failure to comply with the responsibilities of the community, in which case the offender experiences shame as a consequence of the exclusion from and rejection by from the community. A shamed conscience is healed through reconciliation and reinclusion into society (Adeyemo 1998:375).

In a communal culture - such as in African - Van der Walt (2004:12) argues that a transgression is never directly addressed because it may undermine a person's honour. The insult may be even worse than the transgression itself. The community thus address the wrong through indirect manners like gossip, stories, proverbs, parables, dramas and other symbolic actions. In Western individualist culture guilt is internalised. The individual knows that he/she transgressed and feel guilty about it, even though others may not know about it.

The difference then is that in individualistic cultures the transgression of norms leads to a guilty conscience and a fear of being punished. In more communal cultures the failure to life up to the expectations of the community, leads to fear of being rejected and a feeling of shame (Van der Walt 2004:12).

Van der Walt may be generalising. Interesting exceptions are often found within African culture. When a diviner finds that some kind of illness or misfortune is the result of a spirit or ancestor being neglected, steps are immediately taken to rectify the situation: Rituals are performed, family members cared for and wrongs set right (Thorpe 1991:60-61). This the guilt culture more than a typical shame culture. It also happens in the worst of cases when witchcraft is suspected. When the offending witch is sought and possible candidates (usually the descendents of convicted witches and antisocials) interrogated, Shona suspects may be quick to confess. Since it is believed that a witch can do evil unwittingly, the accused are often unsure of themselves (and their innocence) and may confess to being a witch in the hope of being restored to the community through exorcism (Thorpe 1991:64; 
Kgatla 1995:127-128). It seems that evil may be objectified and dealt with quite speedily.

If shame and guilt are understood against the background of my theory, it makes sense. African people's concern for harmony in the community stems from their view that the community is the main theatre for human activity and the integrity of the community is more important than some abstract norm that does not immediately derive from the community. The "shame" (as Van der Walt calls it) may not simply be a superficial fear of being found out, but a genuine fear of compromising the community. And when Africans do seem to objectify evil as something outside of the community, as in the case of exorcisms, it may be because what is usually seen as above, is actually also part of the below.

\subsection{Sin and reconciliation}

The Western tendency to privatise religion determined the Western Christian understanding of sin during much of Church history. Western theology usually sees sin as something that God punished us for, instead of something that God rescues us from. This understanding of sin led Western missionaries to try to induce a sense of guilt for $\sin$ in their indigenous Christian hearers. $19^{\text {th }}$ Century missionaries with an Enlightenment background often had trouble managing that. They complained that Africans had no sense of religion and no sense of sin. "In their frustration at their failure to induce this sense of guilt for $\sin$, they called Africans incorrigible savages, and various other uncomplimentary names" (Maimela 1985:65; Hayes 1998:175).

Africans' view of sin differs significantly from that of significant segments of Western Christianity. The Africans believe that God is the creator of everything including society. Society, according to their belief systems, is a moral entity since the Creator provided a moral code which directs individual behaviour patterns. However, this moral code can be violated, and any infraction of it is regarded as sin, which earns the displeasure of God. Such sinful acts include immoral behaviour, breaking covenant, ritual mistakes, breaking of taboos, committing an abominable act, offence against God or man and pollution. Thus, while Christians often conceptualise the source of evil as the devil or evil power, African religion tend to locate the source of evil firmly in the human world, in the disruptive ambitions and jealousies of people. Such people are witches or sorcerers. Sin creates imbalance in the relationship between God and man or between man and man. Such imbalance is usually attended by catastrophe not only to the offender but also to the whole community (Maimela 1985:65; Mbiti 2005:1; Ndwandwe 2000:213; Thorpe 1991:114; Turaki 1999:141; Ubruhe 1996:18). 
African religion is thus a moral or ethical religion that dictates a certain way of living and relating, the purpose of this ethical consideration being life in its fullness. Africans quickly draw ethical conclusions about thoughts, words, and actions of human beings, or even of "natural" cosmological events, by asking questions such as: Does a particular act or happening promote life? If so, it is good, just, ethical, desirable, and divine. Or, does it diminish life in any way? Then it is wrong, bad, unethical, unjust, or detestable (Magesa 1997:77, 285; Ndwandwe 2000:213).

What traditional Christianity abstractly calls "sin" or "evil" is better expressed in African religion by the concept of "wrongdoing", "badness" or "destruction of life". Although the more abstract notions of sin exist within the African religious consciousness, African religion's moral perspective is concrete and pragmatic. The African concept of $\sin$ is therefore conditional. Sin does not exist in an absolute sense but always within the community and creation. Sin depends on the context and community, and not only otherworldly norms (Magesa 1997:161; Ndwandwe 2000:213).

There is agreement among researchers that African Theology sees sin as a transgression within the community. If humans mistreat one another, it displeases God. When they reconcile, they are by the same token also reconciled with God. There is no need to placate God (or other agencies) (Shenk 1995:76). According to Zulu (1998:191), “... the most striking aspect (of African society) is the willingness to forgive and not to avenge, and there is no emphasis on punishment ... but on making friends again". As below, so above.

\subsection{Liberation}

One of the most significant contributions of African Theology is its emphasis on liberation. African liberation theology revolted against the spiritual enslavement of African people and against the loss of their sense of human dignity and worth. The 1985 Kairos document ${ }^{4}$ went further by not only attacking the State Theology, but also what it calls the Theology of Reconciliation of the mainly English-speaking churches for not opposing the state adequately (Mbiti 1998:152):

In our situation today it would be totally unchristian to plead for reconciliation and peace before the present injustices have been removed. Any such plea plays into the hands of the oppressor by

\footnotetext{
${ }^{4}$ The Kairos document was drawn up by a group of Christians in Soweto during the first State of emergency in 1985 when fierce confrontations were taking place in the townships. The authors demanded a fresh look at the role of Christians in South Africa and a clear call to the church to respond (Kritzinger 1988:127-128).
} 
trying to persuade those of us who are oppressed to accept our oppression and to become reconciled to the intolerable crimes that are committed against us. That is not Christian reconciliation, it is sin. It is asking us to become accomplices in our own oppression, to become servants of the devil. No reconciliation is possible in South Africa without justice.

(Kairos 1985)

These sentiments are still prevalent in South Africa today focussing on new issues. Many Africans seem frustrated by the way liberation was realised in South Africa. It may be because the liberation that was achieved was more on an abstract level, than on a concrete, human level. Many are still not better of than they were during the days of Apartheid: Crime, education, unemployment and housing are for many still a problem. This is political liberation without being liberated from everyday concerns. For Africans, it simply does not make sense. If reconciliation must primarily be achieved within the community, so too must liberation. If the community is not healed, if there is no restitution, there is no liberation. Once again, the community is seen as the place where human dignity and justice must by established. The below precedes the above.

\subsection{Ancestors}

The role of the ancestors is a contentious issue for many African Christians. The majority of mainline African Christians probably follow the early missionaries' advice and distanced themselves from the veneration of the ancestors. But a number of prominent African Theologians - many of them Roman Catholics - have started questioning this, and tried to explain that venerating the ancestors is not necessarily identical to worshipping them, it is not idolatry. The African Initiated Churches often involve the ancestors in their theology, or replace them with new kinds of intermediaries.

I believe that even the importance of the ancestors can be understood in terms of their being "below". The horizontal focus may explain that because the ancestors are still part of the community, humans must cherish their relationship with them as a way of maintaining God's created order. Crafford (1996:15) believes that there is no such thing as ancestor worship since the ancestors are not worshipped as if they were gods. Instead, they are revered as members of the community having greater status and power, and may at times even be regarded as behaving arbitrarily and are argued with.

The ancestors also represent the ideal community and serve as a model for their descendents of what their communities should be like. 


\section{As below, so above: A perspective on African Theology}

Imitating the ancestors is a kind of cure-all for bickering factions and guiltridden individuals (Tutu 1996:xvi; Zulu 1998:188). According to Zulu (1998:187) "The ancestors in African society serve as a model of perpetual peace and harmony to be emulated."

On another level they are also simply closer to the community, which may qualify them to become useful intermediaries. Because they are still in a sense people, they are the best intermediaries between people and God. Not only are the ancestors bilingual as they speak the language of men and the language of God and the spirits, they also know the needs of humans having recently been human themselves.

\subsection{Eschatology}

It is often said that Africans do not have an eschatology. They look back to a golden era when all lived in harmony, and have little awareness or interest in the future. In Mbiti's (1969:16-17) well-known explanation of the African concept of time, he makes the point that for Africans the future extends to a period of about six months - two years at the most. Events outside this range lie beyond what constitutes actual time. "At most we can say that this short future is only an extension of the present" (1969:17).

Modern changes that swept through Africa during the last century, brought an awareness of a brighter future for many Africans with sometimes dangerous consequences. Mbiti (1969:221) explains:

Their hopes are stirred up and set on the future. They work for progress, they wait for an immediate realisation of their hopes, and they create new myths of the future. It is here that we find the key to understanding Africa political, economic and ecclesiastical instability.

As a result, many African Christians have a futuristic hope of an immediate arrival of paradise. They cannot, according to Mbiti (1969:235) "conceive the possibility that the end of the world is an ultra-historical myth which cannot be fitted into the immediate conceptualisation of individual men and women". They are bitterly disappointed when their Christian relatives start to die. Can it be because our Christian eschatology, brought to Africa by missionaries, is too otherworldly and abstract? That it has little bearing on the community? If so, isn't this also due to my theory? At least the African emphasis on the past can be understood in terms of the community; it is closer. 


\section{EVALUATION}

African Theology seems to be humane and practical and as such offer refreshingly undogmatic views on God, sin and the future. Its focus is decidedly this-worldly, and it addresses the problem of evil and strife from a human perspective and has the intention of offering solutions and explanations for humans. Therefore there is little use for extra-contextual myths and models to solve the problem of evil for example. Rather, evil and strife are described from below and human answers are sought. This empowers its adherents (Bediako 1995:101; Du Toit 1998:393).

But is it also Christian? Is "as below, so above" compatible with the Christian message? Can the community or the horizontal dimension be the departure point? A number of theologians seem to think so:

\subsection{God in the community}

The African contention, that the community is the primary arena of interaction between humans and God may well be closer to the Biblical message than Western metaphysics. John Milbank (1997:273-274) and also Ruether (2002:xv) asserts that the idea of the community is thoroughly Christian, and shows that Christ overcomes evil in community with his followers, providing a memory of perfect community and a new language of community:

The Christian claim is that the narratives about Christ show what love - a difficult and demanding practice requiring more subtlety, style, and correct idiom than mere "well-meaning" - is. That here is the Logos, the lost harmonic pattern of genuine human life, which can now be reappropriated.

(Milbank 1997:273)

It seems that the community may not only be a prime example of brokenness and wickedness, but a harmonious community may instead be home to God's self-revelation. Within the healthy community, human beings prosper and because of the support of a community, one can grow. According to Desmond Tutu (1999:35):

A person with ubuntu is open and available to others, affirming of others, does not feel threatened that others are able and good; for he or she has a proper self-assurance that comes from knowing that he or she belongs in a greater whole and is diminished when others are humiliated or diminished, when others are tortured or oppressed, or treated as if they were less than who they are. 


\subsection{Sin is conditional}

I have noted that Africans see sin as a breach of or a threat to the community. Kgatla (1995:126) explains that "sin is inherently the destruction of the group's solidarity, so that a person sins, not against God, but against others". Thus sin is conditional - determined by the context, the actors, time and place, et cetera (Nolan 1988:192; Theron 1996:118-119).

Kgatla (1995:126) adds that the African view of sin is similar to that of ancient Israel:

In ancient Israel sin in life could not be separated from the notion of the covenant relationship. This means that the relationship between Yahweh, and individual and the rest of the community should never be disturbed by actions which were forbidden by law. Any behaviour which threatened the natural carrying on of life in the community was considered as a sinful deed.

This view has significant implications for traditional theology. If sin is indeed as African Theologians contend - conditional, Christian theologians will need to revisit a concept like "The Fall". James Miller (1989:17) calls for a postmodern theology to do just that:

If we are to speak in an illuminating way about evil in the universe, or, more particularly, about pervasive evil in human experience, then we need new stories which account for the reality of our experience of sin, stories which do not assume that the contemporary experience of evil is in some way a mechanical consequence of the act of a prehistoric ancestor.

\subsection{This world and the next}

The African emphasis on this world and on human beings as the principal actors is a corrective of much of Western Christianity's theological overemphasis on the otherworldly. This has caused some theologians (like Adeyemo 1998:372) to label the African worldview as utilitarian. This can possibly be true when this-worldliness is exaggerated. Nevertheless, religion and especially Christianity as the religion of the Incarnation should be incarnate and human (Crafford 1993:176; Meiring 1975:116).

Manas Buthelezi (1976:177): wrote in the 1970's that Christians made a "false unbiblical dichotomy" between human life and Christian life: 
This explains the present anomalous situation in which sometimes those who profess to be concerned with spiritual regeneration often harbour blind spots in their conscience when it comes to questions of human rights and racial justice. In the United States the Southern "Bible Belt" has for many years been at the same time a haven for the Ku Klux Klan and other professing racial bigots. In our own country the national Christian zeal to keep the Sabbath holy is not deemed contradictory to the parliamentary knack for creating discriminatory legislation that subjects black human beings to indignity.

Another example is the so-called "shame conscience" as van der Walt (2004:2-15) typifies the African inclination. The Western guilt conscience often rests on the acceptance of certain absolute norms that easily become detached from society. If norms or moral codes do not directly influence or touch the community, what good are they? How do they make sense? Within the context of Christianity, many norms are ascribed to the untestable will or benefit of God. But is it not true that God wants what is best for the community or at least creation? Shouldn't all norms be tested as to their usefulness for the community? And then, isn't a shame conscience more sensible - if not more biblical? I believe that because a shame conscience is contextual, it is better.

Is it possible that the African worldview can teach the West something about eschatology? Traditional Western Christianity is more otherworldly inclined (Bosch 1989:142). That is why, according to Zygmunt Bauman (1998:59), Christianity had to encourage people to focus on their posthumous fate; put more crudely, Christianity had to produce consumers for its product. Michel Foucault (in Bauman 1998:59) wrote that:

... all those Christian techniques of examination, confession, guidance, obedience, have one aim: to get individuals to work at their own 'mortification' in this world. Mortification is not death, of course, but it is a renunciation of this world and of oneself: a kind of everyday death. A death which is supposed to provide life in another world.

Bauman (1998:63-69) suggests that our society has undergone a "antieschatological revolution", whereby human beings are more concerned and insecure about their human identity, existence and everyday problems, and less interested about their posthumous fate. 
Unlike the ontological insecurity, identity-focussed uncertainty needs neither the carrot of heaven nor the stick of hell to cause insomnia. It is all around, salient and tangible, all-too-protruding in rapidly ageing and abruptly devalued skills, in human bonds entered until further notice, in jobs which can be taken away without any notice, and in the ever new allures of the consumer feast, each promising untried kinds of happiness while wiping away the shine of the tried ones.

(Bauman 1998:68)

Postmodern theologians argue that Christianity should not try to change the insecurities and insufficiencies of human beings, but rather address their real needs. Modern humans' problems are this-worldly: Christianity should give people this-worldly answers. I believe African Theology may show the way.

\subsection{Ecology and holism}

African religion offers a worldview of connectedness where all the elements of creation are woven together. This qualifies the human prominence and also emphasises the human community, the ancestors, nature, spirits and God. Humans, their morality and their needs, cannot be separated from this wider community. God is also part of this larger community. As such, God is also touched by humans' actions towards creation, and vice versa. Both sin and reconciliation have as much to do with the physical as the spiritual dimensions - the physical body and the spiritual being (Adeyemo 1998:374; Crafford 1993:176; Kobia 2003:95; Thorpe 1991:123). This differs significantly from the Western mentality which, according to Daneel (1989:251) is: " ... conditioned by a dichotomous, dualistic anthropology which divides man into two separate entities - 'soul' and 'body'. This view concurs neither with Scripture (nor) with the African's traditional conception. Both Pietism and the Social Gospel are products of this dualistic approach ...."

The idea of connectedness has ecological consequences. This idea of the interdependence of all creation is increasingly accepted in the Western worldview and cosmology (Du Toit 1998:392; Thorpe 1991:120).

\subsection{Concerns}

The point of view of African Theology may raise at least two concerns. The first calls for a balance between the community and that of the individual; the second is not necessarily a problem but requires further elucidation: 


\subsubsection{Suffocating community}

There is a broad consensus among theologians that traditional Western Christianity may benefit from the African focus on the community (Daneel 1989:272; Crafford, Boshoff \& Daneel 84:48). Setiloane states that: "Christianity could be enriched immensely if it were to learn from African tradition about community, that is, of the very essence of being" (Setiloane 2000:57).

For me, as a South African of Western descent, the African emphasis on community seems refreshing and exciting, but sometimes a bit frightening too. Surely individualism is not all bad, and the priority of community all good? Just as Western individualism can be both destructive and creative, the allembracing emphasis on the community can also become harmful if the wellbeing of the community is demanded to the detriment of the individual (Lawuyi 1998:186). Of course even the closest community should allow its members to take responsibility for their actions. Huber argues correctly that accountability and collective accountability should never be ignored for the sake of a community (1993:574).

\subsubsection{Sola Scriptura, sola gratia, sola fidei}

I highly value the reformed tradition which places more emphasis on what God does, than on what humans do. Reformed Theology specifically proceed from the "above", from God's initiative and His saving grace, it demands only faith for justification, and regards the Bible as the most important revelation that we have of God. African Theology thoroughly challenges my reformed perspective.

African Theology and Reformed Theology may not necessarily contradict one another: It is interesting that Calvin, in the introduction to the Institutes, said that theology comprises the study of God, man and nature, but that it makes no difference in principle whether we begin with God or man or nature, since dealing with or reflecting on the one automatically entails and leads to dealing with and reflecting on the other two. One of the most profound implications of this Calvinist position is that none of the three subjects of theology - God, man and nature - is (strictly) objectifiable (Calvin 1931:1-4).

Still, the possibility of reconciling these different ways of dealing with God needs more study and clarification. 


\section{CONCLUSION}

I believe that I have shown that the dictum, "as below, so above" provides a valid perspective on African Theology. It is surely not foolproof, but may be a useful key in the dialogue between two distinct theological traditions.

The African emphasis on the community and context seems to reaffirm many aspects of postmodern philosophy and theology. Many of African Theology's insights seem to be a corrective on some one-sided emphases in Western Theology; other ideas may appear too discontinuous with traditional beliefs. Nevertheless, I believe that the old Egyptian, Hermes Trismegistus's wisdom may help us in a very modern world to understand something of God in an uncertain time.

\section{Works consulted}

Adeyemo, T 1998. Clash of two worldviews: African and Western, 369-386.

Orientation 87-90. (Signposts of God's liberating kingdom: Perspectives for the $21^{\text {st }}$ century, Vol 2.)

Bailey, J A 2006. Ancient African's classification of math. www.blackvoicenews.com

Bauman, Z 1998. Postmodern religion?, in Heelas, P (ed) Religion, modernity and postmodernity, 55-78. Oxford: Blackwell.

Bediako, K 1995. Christianity in Africa: The renewal of a non-western religion. Edinburgh: Edinburgh University Press.

Bosch, D J 1989. Salvation: A missiological perspective. Ex Auditu 5, 139-157.

Buthelezi, M 1976. Daring to live for Christ in Anderson, G H \& Stransky, T , F (eds), Mission Trends, 3: Third World Theologies, 176-180. New York: Paulist Press \& Grand Rapids, MI: Eerdmans.

Calvijn, J 1931. Institutie: Of Onderwijzing in den Christelijken Godsdienst. Delft: W D Meinema.

Carr, Burgess 1976. The Relation of Union to Mission in Anderson, Gerald H \& Stransky, Thomas, F (eds), Mission Trends No. 3: Third World Theologies, 158-168. New York: Paulist Press \& Grand Rapids: Eerdmans.

Crafford, D, Boshoff, C W H \& Daneel, M L 1984. Pluralisme as religieuse verskynsel: Die onafhanklike swart kerke en bewegings en groepsverhoudinge in Suid-Afrika. Pretoria: ISWEN.

Crafford, D 1993. The church in Africa and the struggle for an African identity. Skrif en Kerk 14(2), 163-175.

Crafford, D 1996. African traditional religions, in Meiring, P G J (ed), A world of religions: A South African perspective, 1-26. Pretoria: Kagiso.

Daneel, M L 1989. Fambidzano: Ecumenical movement of Zimbabwean independent churches. Gweru: Mambo Press.

Du Toit, C 1998. African hermeneutics, in Maimela, S \& König, A (eds), Initiation into theology: The rich variety of theology and hermeneutics, 373-398. Pretoria: Van Schaik. 
Gerloff, R 1998. Truth, a new society and reconciliation: The Truth and Reconciliation Commission in South Africa from a German perspective. Missionalia 26(1), 17-53.

Hayes, S 1998. African initiated church theology, in Maimela, S \& König, A (eds), Initiation into theology: The rich variety of theology and hermeneutics, 159178. Pretoria: Van Schaik.

Huber, W 1990. Conflict and reconciliation. Theologia Viatorum 17, 38-44.

Huber, W 1993. Toward an ethics of responsibility. Journal of Religion 73(4), 573591.

Kairos Theologians 1985. Challenging the Church: The Kairos Document. Grand Rapids, MI: Eerdmans.

Kgatla, S T 1995. Dark valleys of death and shining stars in traditional African religions. NGTT 36 (1), 124-130.

Kistner, W 1988. The "imprinting" of violence: A challenge to liberation theology. South African Outlook 118(1405), 95-104.

Kobia, S 2003. The courage to hope: The Roots for a new vision and the calling of the Church in Africa. Geneva: WCC Publications.

Kritzinger, J N J 1988. The Kairos Document: A call to conversion. Missionalia 16(3), 126-145.

Landman, C 1998. African women's theology, in Maimela, S \& König, A (eds), Initiation into theology: The rich variety of theology and hermeneutics, 137140. Pretoria: Van Schaik.

Lawuyi, O B 1998. Water, healing, gender and space in African cosmology. South African journal of ethnology 21(4), 185-190.

Magesa, L 1997. African religion: The moral traditions of abundant Life. New York: Orbis.

Maimela, S S 1985. Salvation in African traditional religions. Missionalia 13(2), 63-77.

Makhathini, D D L 1973. Black theology (II), in Becken, H J (ed), Relevant theology for Africa, 14-17. Durban: Lutheran Publishing House.

Mbiti, J S 1969. African religions and philosophy. London: Heinemann.

Mbiti, J S 1998. African Theology, in Maimela, S \& König, A (eds), Initiation into theology: The rich variety of theology and hermeneutics, 141-158. Pretoria: Van Schaik.

Mbiti, J S 2005. Interview on 20 January.

McCutcheon, R T 1999. General introduction, in McCutcheon, R T (ed), The insider/outsider problem in the study of religion: A Reader, 1-11. London: Cassell.

Meiring, P G J 1975. Stemme uit die Swart Kerk. Kaapstad: Tafelberg.

Milbank, J 1997. Postmodern critical augustinianism: A short summa in forty-two responses to unasked questions in Ward, G (ed), The postmodern God: $A$ theological reader, 265-278. Oxford: Blackwell.

Miller, J B 1989. The emerging postmodern world, in Burnham, F B (ed), Postmodern theology: Christian faith in a pluralist world, 1-19. San Francisco, CA: Harper \& Row.

Musopole, A C 1993. Witchcraft terminology, the Bible, and African Christian Theology: An exercise in hermeneutics. Journal of Religion in Africa 23(4), 347-354. 
Ndungane, N 2003. A world with a human face: $A$ voice from Africa. London: SPCK. Ndwandwe, H C N 2000. Reading 1 John in a Zulu context: Hermeneutical issues. Unpublished PhD dissertation, University of Pretoria.

Nolan, A 1988. God in South Africa: The challenge of the gospel. Cape Town: David Philip.

Nyirongo, L 1997. The Gods of Africa or the God of the Bible: The snares of African traditional religion in Biblical perspective. Potchefstroom: PU for CHE.

Ruether, R R 2002. Preface, in Ruether, R R (ed), Gender, ethnicity, and religion: Views from the other side, ix-xv. Minneapolis, MN: Fortress.

Setiloane, G M 1976. I am an African in Anderson, G H \& Stransky, T F (eds) Mission Trends, 3: Third World Theologies, 128-131. New York: Paulist Press.

Setiloane, G M 2000. African Theology. Cape Town: Lux Verbi.

Shenk, D W 1995. Global Gods: Exploring the role of religions in modern societies. Scottdale: Herald Press.

Steyn, G J 2005. A framework for understanding reconciliation in the so-called General Epistles, in Van der Watt, J G, Human, D J \& Steyn, G J (eds), Friendship and love where there were none: Biblical perspectives on reconciliation, 123-134. Pretoria: IMER.

Theron, P F 1996. African traditional cultures and the Church. Pretoria: IMER.

Thorpe, S A 1991. African traditional religions. Pretoria: University of South Africa.

Turaki, Y 1999. Christianity and African gods. Potchefstroom: PU for CHE.

Tutu, D M 1996. An African prayer book. Cape Town: Double Story.

Tutu, D M 1999. No future without forgiveness. London: Rider.

Ubruhe, J O 1996. Traditional sacrifice: A key to the heart of the Christian message. Journal for Theology in Southern Africa 95, 13-22.

Van der Kooi, C 2002. Three models of reconciliation: A Christian approach, in Gort, J D, Jansen, H \& Vroom, H M (eds) Religion, conflict and reconciliation, 104116. Amsterdam: Rodopi.

Van der Walt, B 2004. 'n Skande - Versus 'n skuldgeoriënteerde gewete: 'n Verklaring vir die botsing tussen die Afrikakultuur en die Westerse kultuur. Ongepubliseerde manuskrip.

Van Niekerk, A S 1982. Dominee, are you listening to the drums? Kaapstad: Tafelberg.

Zulu, E 1998. Reconciliation from an African perspective: An alternative view. Old Testament Essays 11(1), 182-194. 